\title{
A comunicação social nas rádios comunitárias legalizadas do Sertão do Piauí ${ }^{1}$
}

\author{
Orlando Maurício de Carvalho Berti ${ }^{2}$
}

\section{Resumo:}

O trabalho reflete sobre o universo dos processos comunicacionais das 30 primeiras rádios comunitárias legalizadas do sertão do Piauí. Procura traçar o panorama dessas emissoras, identificar as rádios que têm mais vínculos e atuação comunitária e também analisar seus papéis sociais e diferenças. Objetiva-se ainda seus processos comunicativos, além de mapear e fornecer visão do funcionamento de cada emissora, entender como ocorre a participação das comunidades, a visão do fazer radialismo e o significado das emissoras consideradas emblemáticas no fazer comunitário. Metodologicamente adota-se um caminho qualitativo, o qual foi desenvolvido com base em pesquisa bibliográfica, estudo documental e pesquisa de campo, cujas técnicas usadas foram: estudos de produção bibliográfica e de documentos virtuais e hemerográficos e realização de entrevistas semi-estruturadas presenciais com membros das emissoras estudadas. As rádios comunitárias pesquisadas têm ampla importância nos espaços em que estão instaladas porque contribuem difundindo informação local e favorecendo o debate sobre novas demandas de cidadania e novos rumos para a região sertaneja piauiense.

Palavras-chave: Comunicação Comunitária; Comunicação Local e Regional; Rádio Comunitária; Processos Comunicacionais; Sertão do Piauí.

\footnotetext{
${ }^{1}$ Artigo científico baseado na dissertação de Mestrado em Comunicação Social: "Os processos comunicacionais nas rádios comunitárias legalizadas do Sertão do Piauí", apresentada ao Programa de Pós-graduação em Comunicação Social da UMESP - Universidade Metodista de São Paulo, sob orientação da profa. Dra. Cicília Maria Krohling Peruzzo, em 25 de março de 2009. E também em conferência ministrada no Encontro Nacional de Comunicação Comunitária de 2010 -Comuni.

${ }_{2}^{2}$ Jornalista formado pela UFPI - Universidade Federal do Piaú́. Especialista em Comunicação Institucional pela UFPI. Mestre em Comunicação Social pela UMESP - Universidade Metodista de São Paulo. Professor e pesquisador em Comunicação Social com ênfase em Comunicação Comunitária, Comunicação Regional e Pesquisa em Comunicação. Atualmente é doutorando em Comunicação Social no último ano e docente da UESPI - Universidade Estadual do Piauí (Teresina PI), URSA - Universidade Raimundo Sá (Picos - PI). Bolsista da FAPEPI - Fundação de Amparo à Pesquisa do Estado do Piauí. E-mail: orlandoberti@yahoo.com.br
} 


\section{Abstract:}

The work reflects on the universe of communication processes of the first 30 community radio legalized in the backwoods of Piauí. It seeks to trace the panorama of these stations, identify the radios that have more links and community activities and also analyze their social roles and differences. Also talks about communicative processes and map and provide insight into the workings of each station, for understand how is the participation of communities, the vision of making radio and significance of the considered emblematic stations in making community. Methodologically adopts a qualitative way, which was developed based on literature review, desk study and field research, whose techniques used were: studies of bibliographical production and virtual documents and semi-structured interviews faceto-face with members of the stations studied. Community radios studied have broad importance in the spaces in which they are installed because they contribute spreading local information and promoting the debate on new demands of citizenship and new directions for the backwoods of Piauí.

Keywords: Community Communication, Regional and Local Communication, Community Radio; Communicative Processes; backwoods of Piauí.

\section{Resumen:}

Este trabajo refleja a cerca del universo de los procesos comunicacionales de las 30 primeras radios comunitarias legalizadas en el sertão del estado de Piauí. El articulo busca trazar un panorama de esas emisoras, identificar las radios con más vínculos y actuación comunitaria y tambien evaluar sus roles sociales y diferencias. El objetivo es compreender sus procesos comunicativos, además de mapear el funcionamiento de cada emisora, entender como ocurre la participación de las comunidades, la visión de su practica radialística y el significado de las emisoras consideradas emblemáticas en su hacer comunitario. Metodológicamente se adopta un camino cualitativo, el cual fue desarrollado en base de investigación bibliográfica, estudio documental y estudio de campo, cujas técnicas utilizadas fueran: estudios de producción bibliográfica y documentales virtuales y hemerograficos, y realización de entrevistas semiestruturadas presenciales con miembros de las emisoras 
investigadas. Las radios comunitarias investigadas tienen amplia importancia en los espacios en los cuales están instaladas porque contribuyen para difundir información local y favorecen el debate acerca de las nuevas demandas de ciudadanía y en los rumbos de la región.

Palabras clave: Comunicación Comunitaria; Comunicación Local y Regional; Radio Comunitaria; Procesos Comunicacionales; Sertão de Piauí.

\section{I - Processos Comunicacionais, Comunidade e a Comunicação Comunitária na construção de uma nova comunicação}

Os processos comunicacionais são uma das formas de explicação dos preceitos da comunicação, como também de caracterização e ajuda de definição da própria Comunicação: desde sua forma intrapessoal (do sujeito, para o próprio sujeito) à comunicação massiva (de um sujeito para muitos, sendo esses muitos: milhares, milhões ou até bilhões, permitindo algum feedback para esse sujeito). Perfazendo sempre um procedimento básico de emissão (quem emite, quem transmite, quem perpassa, quem transpassa, quem instiga), através de um meio (canal de comunicação, onde e através as mensagens são transmitidas entre o emissor e o receptor) e de uma recepção (quem recebe, que é perpassado, quem interage, que é instigado). Os processos comunicacionais derivam das associações, formações de tornarem-se comuns, das igualitariedades, entendimentos, transmissões, compreensões e socializações de mensagens no sentido de tornar-se entendível e/ou compreensível.

Processos comunicacionais também são entendidos em consonância com reflexões trazidas por David K. Berlo (1972) de que quando iniciada a comunicação, respondendo-a e agindo-se na serventia, observância ou análise comunicativa, esta mesma comunicação serve para afetar e influenciar. A comunicação é um processo, citado pelo autor como algo que não tem um começo, um fim, uma sequência fixa de eventos. Não é coisa estática, é móvel. 
Os processos comunicacionais, apontados por Juaz Díaz Bornenave (1987, p.31), servem para que ocorra na comunicação: expressões, perguntas, respostas, informações, solicitação de informações, ensino, revelações, ocultações, preparações, acusações, queixas, mostras, diversões, risos, choros, preocupações, despreocupações, despertar de curiosidades, satisfações com curiosidades, chamados de atenção, distrações à atenção, ordenações, aceitação de ordenações. Também servindo para confirmar a autodefinição e a autoimagem que a pessoa tem de si mesma, ou para desconfirmá-la, ajudando a formar a personalidade dos indivíduos. A comunicação não é um ato isolado, ou uma série de atos individuais desconexos, mas um fluxo contínuo, de muitas origens e direções, com conteúdos e formas em constante mutação. Vera Teixeira de Aguiar (2004, p.11) afirma que a palavra comunicação vem do latim communicare, com significação de: "tornar comum", "partilhar", "repartir", "associar", "trocar opiniões", "conferenciar".

Esses processos da Comunicação só ocorrem por conta da mediação comunicacional, que, por si só já justifica o parâmetro da troca de informações, da socialização das mesmas e utilização dos preceitos comunicacionais na possibilidade da construção de uma sociedade mais igualitária.

\subsection{Comunidade, conceitos do ontem ao hoje}

No atual espaço de debates comunicacionais, sociológicos, humanísticos aplicados em prol de intencionalidades de um mundo melhor e uma sociedade mais justa e igualitária, e também nos debates e profusão de novas ideias, de novas descobertas e redescobertas dos atos sociais, das novas formas de convívio social e da reverberação comunicacional transformadora, entremeio às novas tendências, abre-se um outro espaço para o local, ganhando-se novas tônicas, principalmente nas discussões sobre comunidade: seu papel, sua interrelação, sua relação, suas lições e permanência em um ambiente cada vez mais global, mas que tem urgentemente mais necessidade de ser mútuo. São reaflorados debates, reeditandose múltiplos pensamentos e trazendo-se novos e polêmicos conceitos em uma sociedade cada vez mais transformada, sem desprezar os conceitos-base e influências de outros setores que, ao menos durante a Idade Moderna, vêm tentando 
compreender as práticas de vivências coletivas e a socialização de ideias e ideais, principalmente via utilização dos processos comunicacionais e da relação destes com as comunidades.

Comunidade hoje pode também ser entendida como um local isolado geograficamente nos confins das regiões distantes do País, ou nos grandes centros, socialmente desassistidos, bem como com membros que procuram identidades próprias.

As comunidades são consideradas hoje locais "esquecidos" ou quase não assistidos pelos poderes públicos constituídos (infelizmente, grande maioria no Brasil). Constata-se que a comunidade territorial-local, enquanto ambiente de vivência, de socialização é lugar de união, de mais sentido coletivo e ainda mais social. Armand e Michèle Mattelart (2003, p.31) destacam que comunidade é definida por três elementos: uma população organizada em um território, em maior ou menor medida nele enraizado, cujos membros vivem em uma relação de interdependência mútua de caráter simbiótico. Os conceitos clássicos de comunidade vêm do sociólogo alemão Ferdinand Tönnies (1995), pensados ainda no século XIX e que trouxeram o ideário de comunidade universal e perfeita, em alemão Gemeinschaft, sendo a comunidade um organismo vivo, enquanto a sociedade, Gesellschft, é agregada de mecanismos e artificialidades. As origens sociais na comunidade possibilitam três tipos de vivência comunitária, como comenta Raquel Paiva (2007, p.135) sobre os ensinamentos de Tönnies: comunidade consanguínea, existente por conta de laços de parentesco, comunidade de proximidade, existente por conta dos laços de vizinhança, e comunidade espiritual, existente por sentimentos, interesses e afetos comuns.

Outro importante teórico que discute comunidade, aperfeiçoando e modernizando os ensinamentos deixados por Tönnies é Martin Buber (1987, p.3339), que evolui sobre os conceitos seminais, pregando a comunidade como também um organismo vivo configurado pelo Eu e pelo $T u$, ou seja, pelo espírito comunal das pessoas e dos grupos formados por essas pessoas, rejeitando o individualismo atomístico (o ser sozinho) e o coletivismo totalitário (vivência em grupo, mas forçada), mas sim de um espaço mútuo e intermediário entre esses dois tipos de 
convivência social. Martin Buber discute também sobre o papel da comunidade como espaço de socialização.

Já Zygmunt Bauman (2003, p.129), ao destacar os conceitos de comunidade visando as relações do século XXI, traz a ideia de comunidade de compartilhamento, em conceitos mais coletivizantes. O autor também destaca a ideia de comunidade como local de cuidado mútuo, sendo um avanço sobre sua interação social, onde ainda haja direitos iguais e igual capacidade coletiva de ação em relação à defesa dos direitos (humanos, sociais, coletivos e plurais). Marcos Palácios (1995) enfatiza que a comunidade é uma invenção da modernidade, onde as comunidades são pensadas enquanto tal e não mais vivenciadas enquanto ambientes sociais. Ele reflete sobre cinco elementos necessários para se identificar uma comunidade: o primeiro é o sentido de ligação e pertencimento, ou seja, os membros têm de se sentir parte; o segundo é o sentido cooperativo, de ajuda e solidariedade; o terceiro é a permanência em contraposição à efemeridade; o quarto é a territorialidade e aí ele traz não só como território real, mas também território simbólico; o quinto é a existência de uma forma própria de comunicação entre seus membros, através de veículos específicos.

\subsection{Comunicação Comunitária}

$\mathrm{Na}$ diversidade dos processos comunicacionais do século $\mathrm{XXI}$, suas segmentações trazem uma série de formas de expressividades e instigam novas vivências. Uma delas é o lado cidadão (ou de possibilidade de cidadania), participativo (ou de possibilidade de participação), e ainda fraternal e coletivo, voltado para as comunidades, localidades ou lugares mais esquecidos pelos poderes públicos, que ajudam a definir as áreas e abrangências de atuação da Comunicação Comunitária.

Entende-se como Comunicação Comunitária a comunicação das comunidades, feitas nas comunidades e para as comunidades, também sendo presente em localidades e grupos que se assumem como comunidades ou nichos comunitários, dando vazão às suas vozes, ideias e ideais, geralmente em contraponto aos meios de comunicação tradicionais (que raramente dão voz e 
espaço a essas comunidades e grupos) ou nova forma de visão, mesmo sendo reverberada por outros meios, frente às mídias tidas como tradicionais e historicamente massivas, não socializantes em certos aspectos que ocorrem nas comunidades. Os meios de comunicação comunitários, segundo a professora Cicília Peruzzo (2007a, p.190) têm potencial de ser, simultaneamente, parte de um processo de organização popular e também canais carregados de conteúdos informacionais e culturais, possibilitando a prática das participações diretas nos mecanismos de planejamento, produção e gestão. Ela ainda destaca que não são todos os meios de comunicação presentes nas comunidades que podem ser considerados meios de comunicação comunitários, principalmente por conta das conjunturas e até da forma com que alguns ideais são desviados, mas os meios que assumem esse papel contribuem duplamente para a construção da cidadania. Os meios de comunicação comunitária ainda envolvem-se no dia a dia do local em que estão instalados.

Essa comunicação, ainda pelo pensamento de Cicília Peruzzo (1998a, p.152), gira em torno das questões da informação, educação, arte e cultura, com espaços para entretenimento, prestação de serviços, participação de várias organizações e divulgação de manifestações culturais locais. Um dos fortes fatores da comunicação comunitária é sua forma de instigar a participação, principalmente dos membros da comunidade e dos grupos em que os meios de comunicação comunitários estão inseridos.

Participação nos meios de comunicação, segundo PERUZZO (2007b, p.10), que parte dos conceitos do pensador latino-americano José Merino Utreras, pode ocorrer em quatro níveis. O primeiro é o da participação nas mensagens, através da concessão de entrevistas, solicitação de músicas, e de outros pedidos mais básicos; o segundo nível é o da participação na produção de mensagens, materiais e programas, elaborando-se e editando-se o que será veiculado nos meios de comunicação comunitária; o terceiro nível é o da participação no planejamento, com a comunidade envolvendo-se no estabelecimento de políticas do meio, bem como nas elaborações e planos de formatação dos veículos e das programações e o quarto e mais profundo nível é o da participação na gestão do meio de comunicação comunitário, com participação nos processos de administração e controle do meio. 
A Comunicação Comunitária, também em concordância com Cicília Peruzzo (1998a), pluraliza, está em sintonia com especificidades de cada realidade onde está inserida e ainda, instiga a participação ativa de entidades não governamentais e sem fins lucrativos. São novas vozes, caminhos, formas de comunicação e de se trazer vozes polissêmicas, de se participar, interagir e vivenciar essa ótica comunitária. Esses caminhos ganham espaço na Academia, mesmo ainda de forma um pouco tímida, onde 0 interesse de pesquisar, estudar e entender tais movimentos, tais caminhos e tais diferenciações para com as mídias convencionais vem aos poucos gerando interesse dos acadêmicos, sendo realizados trabalhos de conclusão de curso, dissertações e teses, retratando esses movimentos, essas formas de comunicação social.

Raquel Paiva (2007, p.137-147), ao debater sobre as novas interfaces da comunicação comunitária, destaca que existem oito pontos para a justificativa da perspectiva comunitária no campo comunicacional. São eles: a comunicação comunitária constitui uma força contra-hegemônica no campo comunicacional; a comunicação comunitária atua na direção de uma estrutura polifônica; a comunicação comunitária produz novas formas de linguagem; a comunicação comunitária capacita-se para interferir no sistema produtivo; a comunicação comunitária gera uma estrutura mais integrada entre consumidores e produtores de mensagens; a comunicação comunitária atua com o propósito primeiro da educação; a comunicação comunitária pode engendrar novas pesquisas tecnológicas; a comunicação comunitária como lugar propiciador de novas formas de reflexão sobre a comunicação.

\section{II - Comunicação local e regional}

A comunicação se constitui de múltiplos processos e contempla as mais diferentes manifestações, principalmente em explicar os procedimentos de emissão, mensagens e recepção. Uma dessas formas de processos comunicacionais se dá nos lugares, entendendo-se lugar como espaço de relações, aqui enfocados nos níveis regional e local. Nos espaços locais e regionais ocorrem maiores produções para quem está mais próximo aos espaços, destacando-se, vivendo-se, 
socializando-se mais facilmente e com maior fortificação do "aqui", do "local", do “perto".

Esses processos comunicacionais, principalmente nos âmbitos regional e local são também mais segmentados e menos globalizantes, menos pasteurizados do que aqueles de nível nacional. As identidades estão mais evidentes localmente e regionalmente, mas não deixam de interagir com o global, visto que não há paredes que prendam os processos comunicacionais e, muito menos, que os impeçam de serem socializados além desses espaços.

As interfaces dessa interação é que são um dos principais pontos de permeabilidade do local, principalmente quando ligado ao comunitário. As peculiaridades do local e do regional também ajudam a explicar o fenômeno das novas tendências dos processos comunicacionais da contemporaneidade, elencando novas pluralizações, mediações, transmissões e socializações de informações, principalmente no sentido desses processos serem entendidos como formas de comunicação social. O local e o regional, notadamente em relação ao pensamento comunicacional brasileiro, sempre foram amplos espaços sociais, que congregam e firmam as relações sociais (surgidas na localidade e historicamente não menos importante, expandindo-se para o regional, congregando vários "locais").

Era no territorial e no lugar que ocorriam os processos comunicacionais, principalmente antes dos inventos tecnológicos que despontaram a partir do século XX e puderam socializar a massividade à comunicação social, podendo chegar a muito mais localidades e territórios.

Com a propagação de invenções como o rádio, a televisão, e muito mais tarde: a Internet e a possibilidade de ampliação do acesso à leitura, esse poder de congregação comunicacional local foi deixado de lado, ou ao menos desprezado, para dar lugar a práticas da comunicação de forma mais nacional e internacional, principalmente pelos termos estrondosos de valorização financeira desses eventos e da possibilidade de ampliação dos mercados também revertidos em produtos comunicacionais e culturais para serem consumidos de forma massiva.

O atual desenvolvimento do regional e, consequentemente do local, é apontado por Anamaria Fadul (2006, p.23) como uma consequência da descentralização dos industrial dos grandes centros beneficiando as regiões 
Nordeste, Centro-Oeste e Norte, regiões historicamente integradas em uma visão dominante das regiões Sudeste e do Sul, deixando-se de lado as manifestações populares, culturais, feitas da, para e na região, da, para e no local. Rogério Bazi (2001, p.11-19) destaca que a regionalização é um dos caminhos da comunicação no século XXI, ao retratar os assuntos locais, proporciona o acompanhamento do que ocorre no país e no mundo.

No local recebe-se e filtra-se o nacional, o mundial e até o regional, retroalimentando os processos comunicacionais, agora não mais com uma visão nacional, mas regional e local.

A Comunicação desenvolve-se nesses nichos, principalmente no comunitário, como afirma Jorge Pedro Sousa (2003, p.87), por conta das proximidades e interações, aglutinadas em grupos de valores, famílias, modos de vida, interesses e línguas comuns.

\section{III - O Sertão Nordestino e sua histórica exclusão}

O Sertão Brasileiro (ou semi-árido) é uma das áreas mais pobres, mais esquecidas e mais desvalorizadas (em termos sociais) do País. É uma região de paradoxos, notadamente por ter forte e tradicional cultura, e ainda possuir, em relação a outras regiões do Brasil, um dos maiores potenciais de crescimento social, econômico, cidadão e, também, comunicacional, com grande ênfase à comunicação feita por instituições e movimentos sociais ligados à manutenção das tradições locais culturais e a melhoria da vida do sertanejo. O sertão é a região que congrega áreas do País com pequeno número de precipitações pluviométricas (chuvas) de médias anuais inferiores a 800 milímetros, com índice de aridez (secura do solo) extrema e risco anual de estiagem (seca) maior que $60 \%$.

O sertão brasileiro ocupa uma área de 969.584,4 quilômetros quadrados, compreendendo 1.133 municípios, com população de 20.858 .264 habitantes (44\% desse contingente vivendo em regiões rurais). O sertão do Brasil, segundo o IBGE Instituto Brasileiro de Geografia e Estatística (2009), abrange grande parte dos estados nordestinos de: Alagoas, Ceará, Bahia, Paraíba, Pernambuco, Piauí, Rio Grande do Norte e Sergipe, além de uma porção Norte (conhecida por Vale do 
Jequitinhonha) do estado de Minas Gerais (que fica no Sudeste). Ele corresponde a $11,38 \%$ do território nacional (dos 8.514.876 quilômetros quadrados de área total do País), e a 10,87\% da população (dos 191.790 .900 habitantes do País). Nessa região também encontram-se 20.858.254 dos 51.534.406 habitantes do Nordeste e a $20,36 \%$ do número de municípios brasileiros (dos 5.564 existentes). Se fosse um País, em termos territoriais, o Sertão do Brasil seria o 30 maior país do Mundo, logo após o décimo maior do Hemisfério Sul, o oitavo maior das Américas e o quinto maior da América do $\mathrm{Sul}^{3}$, não havendo, inclusive na Europa, nenhum país que superasse o seu tamanho territorial.

Comunicacionalmente, o sertão do Brasil é a região do País com a maior concentração de meios de comunicação (principalmente canais de rádio e TV) nas mãos de políticos, que são artífices e impulsionadores das grandes negociações em Brasília, sendo geralmente ocupantes de cargos de chefia na Câmara dos Deputados, Senado e ainda os principais órgãos estatais federais, reverberando seus poderes também nas esferas estaduais e locais do Sertão.

\subsection{O Sertão piauiense}

O Piauí, segundo o IBGE (2009), tem uma área de 251.529,186 quilômetros quadrados (sendo o 11ำ maior estado do País), com população de 3.032 .421 habitantes (sendo o décimo sétimo mais populoso estado da Nação). O sertão do Piauí é delimitado através do Decreto Estadual número 11.292, de 19 de janeiro de 2004 (SECRETARIA DE FAZENDA DO PIAUÍ, 2009). Essa parte do Sertão do Brasil é composta por 151 municípios $^{4}$ dos 224 do Estado, ou $67,41 \%$ do total de municípios piauienses. O Sertão piauiense ocupa uma área de 155.762 quilômetros quadrados (ou $61,93 \%$ do território piauiense) com 1.280 .753 habitantes (42,24\% da população estadual e 6,14\% da população do sertão do Brasil). Antes da existência

\footnotetext{
${ }^{3}$ Com cruzamento de dados do IBGE PAíSES (2009).

${ }^{4} \mathrm{O}$ decreto original previa 148 municípios, sendo anexados em 2004 os municípios de Domingos Mourão e Pedro II, no Norte do Estado. Em 2005 a região contou com mais um município: Aroeiras do Itain, desmembrada da também cidade sertaneja de Picos, no Centro-Sul do Estado.
} 
da província do Piauí, essa região sertaneja foi subordinada durante os primeiros 200 anos de colonização portuguesa no Brasil à Bahia e depois ao Maranhão.

\section{IV - O papel das rádios comunitárias nos processos comunicacionais}

As rádios comunitárias são uma das categorias de meios de comunicação social radiofônico existente no Brasil entremeio a rádios: convencionais, públicas, educativas, livres, de poste, cada uma com seu modo e intencionalidade de reverberar, através de sons, processos comunicacionais, geralmente massivos e com vivências, confluências, consequências próprios, o que torna esse meio uma das maiores e mais heterogêneas formas de pluralização da comunicação.

Por serem orais, instigando principalmente a audição de quem acessa os produtos comunicativos, as rádios trazem 0 entendimento dos processos comunicacionais com maior rapidez, notadamente por serem de fácil acesso (devido aos aparelhos de rádio custarem menos do que outros eletro-eletrônicos e, na maioria das vezes, portáteis, não custando muito mantê-los), não necessitando leiturabilidade visual, visto que também se torna útil e popular por conta do grande índice de analfabetismo funcional no País, além de haver o maior número de meios de comunicação desse tipo no Brasil, principalmente nas regiões mais pobres, hoje, ainda majoritárias no território nacional.

Uma emissora de rádio tem também a possibilidade de ser a principal forma de representação e de reverberação dos ideais comunitários, ou ainda dos ideais nos âmbitos: regional e local, principalmente por conta dessa proximidade e fidelização com o receptor.

José Eugênio de Oliveira Menezes (2007, p.22-24) destaca que as emissoras de rádio contemplam diversos fios de tempos e vozes que se misturam na vida de um lugar, e ainda possibilitam a sincronização da vida em sociedade, promovendo, em termos de sensações, a criação de cenários mentais e imagens endógenas, ou seja: próprias para o cidadão receptor. $\mathrm{O}$ rádio tem $\mathrm{o}$ poder de transformar e construir novas sociabilidades, mudando lugares, pessoas, mentalidades e instigando uma sociedade mais justa, principalmente se tiver por trás pessoas compromissadas e unidas com causas coletivizantes. José Ignácio López Vigil 
(2003) aumenta a discussão trazendo o que considera "rádios espelhos" e "rádios janelas", sendo as primeiras: emissoras radiofônicas locais e as segundas: emissoras radiofônicas nacionais. As rádios locais constroem identidades e as rádios nacionais (incluindo-se as regionais) divisam outros mundos e constroem solidariedade. Necessitando-se para o desenvolvimento das sociedades os dois tipos de emissoras radiofônicas.

Nessa segmentação que perfaz a importância das FMs comunitárias, principalmente como meios de comunicação local, "o rádio local nos ensina que não temos menos valor que os outros. A nacional, que não temos mais valor que os outros" (LÓPEZ VIGIL, 2003, p.488). Segundo Denise Cogo (2004, p.45), esse tipo de comunicação, baseando-se, principalmente, em rádios comunitárias locais, vem sendo marcada por demandas pautadas em micropolíticas identitárias e reivindicatórias de setores sociais específicos. Nas rádios comunitárias e livres reivindica-se o que é comum, o que é mais pautado para os interesses daquele nicho comunitário, utilizando-se mídias da e para a comunidade.

\subsection{As rádios comunitárias}

As rádios comunitárias são uma das categorias de emissoras de rádio, numericamente se comparadas às comerciais e às público-estatais, hoje no País em maior quantidade. Em termos de funcionamento e emissão de sinais as rádios comunitárias são iguais a qualquer outra rádio. Operam em Frequência Modulada (FM) e hoje estão presentes em praticamente todas as regiões do Brasil. As primeiras legalizações de emissoras de rádio que utilizam e se assumem como comunitárias só ocorreram há pouco mais de dez anos com a implantação da Lei 9.612, de 19 de fevereiro de 1998, mais conhecida como Lei das Rádios Comunitárias.

O movimento de rádios comunitárias e livres no Brasil é mais antigo que a lei, que foi consequência histórica desse movimento em vários de lugares e de milhares de embates Brasil afora para garantir o direito de transmitir o que ocorria em comunidades e localidades, geralmente não assistidas ou não representadas pelos meios de comunicação convencionais. 
Luiz Artur Ferrareto (2001, p.50) considera também uma rádio comunitária como sendo uma emissora que operam em frequência modulada, com transmissores de baixa potência e antenas não superiores a 30 metros de altura, sendo que essas rádios devem atender às comunidades onde estão instaladas, difundindo ideias, elementos culturais, tradições e hábitos locais, além de estimular lazer, integração, convívio e prestar serviços de utilidade pública. Mesmo existindo lei específica, boa parte das rádios comunitárias no País não estão legalizadas ${ }^{5}$, sendo vítimas de constantes perseguições, ocorrendo até mortes.

Cicília Peruzzo (1998c) destaca que é importante as rádios serem chamadas de comunitárias em vez da nomenclatura de rádios pirata (termo até hoje aplicado principalmente pelas emissoras comerciais ou grupos comunicacionais hegemônicos).

Segundo Raquel Paiva (2003, p.139), "uma das razões para a criação de um veículo comunitário é a vontade de produção de um discurso próprio, sem filtros e intermediários".

É nesse contexto de rádios comunitárias com produção do local e também instigando-se e pautando-se pelo regional que encontram-se as rádios comunitárias legalizadas do sertão do Piauí. Todas essas emissoras já passaram da fase da luta pela legalização, sendo, inclusive muitas delas, pioneiras no movimento de rádios comunitárias no Nordeste.

\section{V - As rádios comunitárias legalizadas do Sertão do Piauí}

No sertão do Piauí até o início de 2008 existiam 30 emissoras de rádio comunitária legalizadas 6 . Até 31 de janeiro de 2009 a mesma região sertaneja brasileira já contava com 37 emissoras de rádio, mas as sete novas FMs autorizadas a funcionar a partir de março de 2008 ainda estavam em fase de instalação, com programação experimental e puramente musical, algumas contando ainda com a construção e reforma de prédios e compra e/ou modernização de equipamentos,

\footnotetext{
${ }^{5}$ Calcula-se que, para cada rádio comunitária legalizada no Brasil haja, pelo menos, outras dez sem serem legalizadas.

${ }^{6}$ Escolheu-se o último dia de fevereiro de 2008 como data limite de recorte, principalmente porque necessitava-se de um fechamento de data para o Exame de Qualificação e ainda para sistematizar a escolha do acompanhamento das emissoras de rádio comunitárias legalizadas nessa região do País.
} 
principalmente porque estavam fechadas e lacradas antes de suas autorizações pelo Ministério das Comunicações.

Como apresentamos em texto sobre a histórica situação de legalização das emissoras de rádio comunitárias no Sertão Nordestino: o sertão do Piauí é a região do País que tem, em termos proporcionais (número de municípios, pelo número de emissoras de rádio), o menor número de emissoras de rádio comunitárias legalizadas do País. O Piauí, como um todo, é o terceiro estado do País a ter o menor número de emissoras de rádio comunitária legalizadas, mesmo o estado sendo uma das doze maiores unidades federativas brasileiras e com presença de meios de comunicação ainda de forma muito tímida e sem muita representatividade comunicacional (BERTI, 2008, p.02-14).

A legalização dessas rádios comunitárias (feitas ainda de forma muito tímida no Piauí) é um dos caminhos de garantia de funcionamento das mesmas, evitandose desgastes, perdas, preocupações de fechamento, além de canalizar esforços para a melhoria da comunidade, localidade e até região em que estão inseridas, e ainda promovendo debates, socializando ideias e tentando melhorar a situação do sertão, principalmente nos locais mais isolados ou que têm poucos ou nenhum meio de comunicação.

Para conhecer as 30 primeiras emissoras de rádio comunitárias legalizadas da história do sertão do Piauí, fez-se um trabalho de campo, com visitas a todas estas emissoras - entre janeiro de 2007 e fevereiro de 2008 - além de novas visitas às rádios consideradas emblemáticas entre junho de 2008 e janeiro de 2009.

Foram consideradas emissoras de rádio comunitárias legalizadas emblemáticas no sertão do Piauí, que têm diferenciais positivos em relação às rádios convencionais e também atividades em relação ao compromisso local e integração com as comunidades.

Ao todo foram percorridos pelo autor mais de 19.000 quilômetros (em doze viagens), tiradas mais de cinco mil fotografias, gravadas quase cem horas de entrevistas e depoimentos, além do conhecimento a fundo da comunicação feita nessa região do País, interagindo com produtores das emissoras e moradores das cidades sertanejas. 
Em cada uma das rádios contextualizamos suas histórias (desde a concepção da ideia de se montar a emissora até a atualidade), lutas pela legalização, atual situação, inclusive como interage com os locais em que estão inseridas, programação, se seus diretores e membros a consideram comunitárias e o seu conhecimento sobre a Lei 9.612/98 (Lei das rádios comunitárias), dentre outras peculiaridades. As frequências das emissoras foram conseguidas por meio de pesquisa de campo e verificação em visitas às cidades e às rádios ${ }^{7}$. Os nomes das entidades mantenedoras foram extraídos da lista oficial do Ministério das Comunicações (2008). A distância das cidades do sertão piauiense à capital denotam do Mapa Rodoviário do Piauí $(1996)^{8}$, sendo fornecidas as distâncias das cidades até Teresina (capital do Estado) e se suas localizações estão à Norte ou à Sul da Capital. Ainda são fornecidos dados da população e também da área territorial dos municípios em que as rádios estão instaladas ${ }^{9}$ (IBGE, 2007) e ainda o IDH - Índice de Desenvolvimento Humano, fornecido pelo PNUD (2008).

\section{QUADRO 1 - RESUMO DOS PRINCIPAIS ASPECTOS DAS RÁDIOS COMUNITÁRIAS LEGALIZADAS DO SERTÃO DO PIAUÍ}

\begin{tabular}{|c|c|c|c|c|c|c|c|c|c|}
\hline $\begin{array}{c}\text { Nome da } \\
\text { emissor } \\
\text { a } \\
\text { do } \\
\text { Sertão } \\
\text { do Piauí }\end{array}$ & $\mathrm{MHz}$ & Cidade & Pop. & IDH & $\begin{array}{c}\text { Kms } \\
\text { da } \\
\text { capital }\end{array}$ & $\begin{array}{l}\text { Única } \\
\text { rádio } \\
\text { da } \\
\text { cidade }\end{array}$ & $\begin{array}{c}\text { Formas de } \\
\text { participação } \\
\text { das } \\
\text { comunidades }\end{array}$ & $\begin{array}{c}\text { Visão de } \\
\text { consideração } \\
\text { como rádio } \\
\text { comunitária }\end{array}$ & $\begin{array}{c}\text { Assume } \\
\text { ligação } \\
\text { com } \\
\text { partidos } \\
\text { políticos }\end{array}$ \\
\hline Ativa & 92,9 & Piracuruca & 25.625 & 0,609 & 196 km & NÃO & $\begin{array}{l}\text { Telefone, cartas, } \\
\text { bilhetes, visitas }\end{array}$ & $\begin{array}{c}\text { Só se considera } \\
\text { comunitária no nome }\end{array}$ & NÃO \\
\hline $\begin{array}{c}\text { Bom } \\
\text { Conselho }\end{array}$ & 104,9 & $\begin{array}{l}\text { São João } \\
\text { da } \\
\text { Fronteira }\end{array}$ & 5.008 & 0,554 & $226 \mathrm{~km}$ & SIM & $\begin{array}{l}\text { Telefone, cartas, } \\
\text { bilhetes, visitas }\end{array}$ & $\begin{array}{c}\text { Se acha comunitária, } \\
\text { mas programação é } \\
\text { convencional }\end{array}$ & $\begin{array}{c}\text { SIM, com o } \\
\text { DEM }\end{array}$ \\
\hline Cidade & 104,9 & $\begin{array}{l}\text { Valença } \\
\text { do Piauí }\end{array}$ & 19.716 & 0,647 & $210 \mathrm{~km}$ & NÂO & $\begin{array}{c}\text { Telefone, cartas, } \\
\text { bilhetes, visitas } \\
\text { e faz } \\
\text { campanhas } \\
\text { beneficentes }\end{array}$ & $\begin{array}{l}\text { Não se acha } \\
\text { comunitária }\end{array}$ & $\begin{array}{l}\text { SIM, com o } \\
\text { DEM }\end{array}$ \\
\hline Eldorado & 87,9 & $\begin{array}{l}\text { Elesbão } \\
\text { Veloso }\end{array}$ & 14.174 & 0,601 & $155 \mathrm{~km}$ & NÃO & $\begin{array}{c}\text { Telefone, cartas, } \\
\text { bilhetes }\end{array}$ & $\begin{array}{l}\text { Se acha comunitária } \\
\text { apesar de ter dono }\end{array}$ & $\begin{array}{l}\text { SIM, com o } \\
\text { PP }\end{array}$ \\
\hline Estação & 104,9 & Brasileira & 7.699 & 0,580 & 172 km & NÃO & $\begin{array}{c}\text { Telefone, cartas, } \\
\text { bilhetes, visitas, } \\
\text { e-mail }\end{array}$ & $\begin{array}{c}\text { Se acha comunitária, } \\
\text { mas repete } \\
\text { programação }\end{array}$ & $\begin{array}{l}\text { SIM, com o } \\
\text { PMDB }\end{array}$ \\
\hline
\end{tabular}

\footnotetext{
${ }^{7}$ Visto que em alguns casos a frequência informada pela autorização da ANATEL não é respeitada ou confunde-se com emissoras da região em que funcionam as FMs de rádio comunitária legalizadas do sertão do Piauí. Para evitar confrontos as frequências são trocadas, geralmente respeitando as frequências do período em que a emissora não era legalizada.

${ }^{8}$ Mais preciso documento cartográfico sobre distâncias do Estado, visto que foi realizado por meio de GPS, com distâncias precisas e tido como o mapa mais respeitado para distâncias do Piauí.

${ }^{9}$ Dados do Censo Demográfico de 2007 (IBGE, 2007), mais atual e mais confiável contagem da população brasileira.
} 


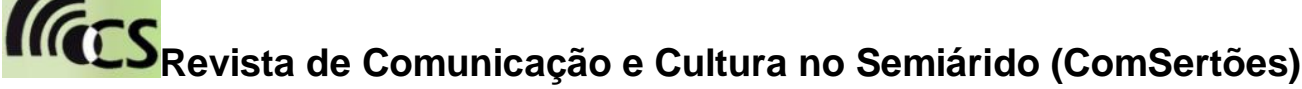

\begin{tabular}{|c|c|c|c|c|c|c|c|c|c|}
\hline & & & & & & & & convencional & \\
\hline Família & 104,9 & Piripiri & 60.249 & 0,641 & $157 \mathrm{~km}$ & NÃO & $\begin{array}{c}\text { Telefone, cartas, } \\
\text { bilhetes, e-mail, } \\
\text { acesso ao sitio } \\
\text { da rádio }\end{array}$ & $\begin{array}{l}\text { Se acha e defende o } \\
\text { comunitário, mas tem } \\
\text { ligação com a Igreja } \\
\text { Católica }\end{array}$ & $\begin{array}{l}\text { NÃO assume } \\
\text { Mas há } \\
\text { ligação com o } \\
\text { PT }\end{array}$ \\
\hline Gety & 100,1 & Curimatá & 10.360 & 0,680 & $775 \mathrm{~km}$ & NÃO & $\begin{array}{l}\text { Telefone, cartas, } \\
\text { bilhetes, visitas }\end{array}$ & $\begin{array}{l}\text { Diz que é comunitária, } \\
\text { mas tem programação } \\
\text { igual a uma } \\
\text { convencional }\end{array}$ & $\begin{array}{c}\text { SIM, ao } \\
\text { PMDB, pres. é } \\
\text { política }\end{array}$ \\
\hline Guaribas & 106,3 & Picos & 70.450 & 0,703 & $311 \mathrm{~km}$ & NÃO & $\begin{array}{l}\text { Telefone, cartas, } \\
\text { bilhetes, visitas }\end{array}$ & $\begin{array}{l}\text { Diz que é comunitária, } \\
\text { mas tem programação } \\
\text { igual a uma } \\
\text { convencional }\end{array}$ & $\begin{array}{c}\text { SIM, ao } \\
\text { PMDB, pres. é } \\
\text { sec. de com. } \\
\text { da cidade }\end{array}$ \\
\hline Liberdade & 87,9 & Oeiras & 35.075 & 0,625 & $313 \mathrm{~km}$ & NÃO & $\begin{array}{c}\text { Só os } \\
\text { evangélicos } \\
\text { para pedir hinos }\end{array}$ & $\begin{array}{c}\text { Rádio para } \\
\text { evangélicos. Faz } \\
\text { questão de ser assim }\end{array}$ & $\begin{array}{c}\text { NÃO mas } \\
\text { houve lobby } \\
\text { de dep. de SP }\end{array}$ \\
\hline Luzes & 87,9 & $\begin{array}{l}\text { Colônia do } \\
\text { Gurguéia }\end{array}$ & 5.700 & 0,641 & $507 \mathrm{~km}$ & NÃO & $\begin{array}{l}\text { Telefone, cartas, } \\
\text { bilhetes, visitas }\end{array}$ & $\begin{array}{c}\text { Acha que é } \\
\text { comunitária, mas a } \\
\text { população participa } \\
\text { muito pouco }\end{array}$ & SIM, PMDB \\
\hline $\begin{array}{l}\text { Malhada } \\
\text { do Jatobá }\end{array}$ & 90,5 & $\begin{array}{l}\text { São João } \\
\text { do Piauí }\end{array}$ & 18.689 & 0,650 & $486 \mathrm{~km}$ & NÂO & $\begin{array}{l}\text { Telefone, cartas, } \\
\text { bilhetes, visitas, } \\
\text { campanhas } \\
\text { educativas, } \\
\text { programas de } \\
\text { entidades } \\
\end{array}$ & $\begin{array}{l}\text { Se acha, notadamente } \\
\text { por sua história e por } \\
\text { dizer que dá espaço a } \\
\text { todos os segmentos } \\
\text { da sociedade }\end{array}$ & $\begin{array}{c}\text { NÃO, mas } \\
\text { muitos são } \\
\text { ligados ao PT }\end{array}$ \\
\hline Marvão & 104,9 & $\begin{array}{l}\text { Castelo do } \\
\text { Piauí }\end{array}$ & 18.550 & 0,596 & $190 \mathrm{~km}$ & NÂO & $\begin{array}{l}\text { Telefone, cartas, } \\
\text { bilhetes, visitas }\end{array}$ & $\begin{array}{l}\text { Se diz comunitária } \\
\text { mas não tenta provar }\end{array}$ & $\begin{array}{c}\mathrm{NÂO} \text {, apesar } \\
\text { de ter }\end{array}$ \\
\hline Matões & 104,9 & Pedro II & 36.675 & 0,605 & $195 \mathrm{~km}$ & NÃO & $\begin{array}{c}\text { Telefone, cartas, } \\
\text { bilhetes, visita, } \\
\text { programas de } \\
\text { instituições } \\
\end{array}$ & $\begin{array}{l}\text { Diz e tenta enveredar } \\
\text { por esse caminho, } \\
\text { notadamente no } \\
\text { jornalismo }\end{array}$ & $\begin{array}{l}\text { NÃO, apesar } \\
\text { de terem } \\
\text { gente no PT e } \\
\text { PCdoB } \\
\end{array}$ \\
\hline $\begin{array}{c}\text { Nossa } \\
\text { Senhora } \\
\text { da } \\
\text { Conceição }\end{array}$ & 105,9 & Bocaina & 4.039 & 0,657 & $324 \mathrm{~km}$ & NÂO & Rádio fechada & Rádio Fechada & $\begin{array}{l}\text { Ligada ao } \\
\text { DEM }\end{array}$ \\
\hline $\begin{array}{c}\text { Nossa } \\
\text { Senhora } \\
\text { da } \\
\text { Conceição }\end{array}$ & 99,5 & São Julião & 5.908 & 0,578 & $382 \mathrm{~km}$ & NÂO & $\begin{array}{c}\text { Telefone, cartas, } \\
\text { bilhetes }\end{array}$ & $\begin{array}{l}\text { Se acha comunitária, } \\
\text { mas tem programação } \\
\text { toda copiando as } \\
\text { comerciais }\end{array}$ & $\begin{array}{l}\text { Ligada ao } \\
\text { DEM }\end{array}$ \\
\hline $\begin{array}{l}\text { Nova } \\
\text { Cidade }\end{array}$ & 87,9 & $\begin{array}{c}\text { Cabeceira } \\
\mathrm{s}\end{array}$ & 9.438 & 0,525 & $93 \mathrm{~km}$ & NÂO & $\begin{array}{l}\text { Telefone, cartas, } \\
\text { bilhetes, visitas }\end{array}$ & $\begin{array}{c}\text { Se acha comunitária, } \\
\text { tem programação } \\
\text { copiando as } \\
\text { comerciais }\end{array}$ & $\begin{array}{c}\text { NÃO, mas } \\
\text { pres. é pref. } \\
\text { ligado ao PTB }\end{array}$ \\
\hline $\begin{array}{l}\text { O Grito de } \\
\text { Ipiranga }\end{array}$ & 90,1 & $\begin{array}{l}\text { Ipiranga } \\
\text { do Piauí }\end{array}$ & 9.354 & 0,601 & $256 \mathrm{~km}$ & SIM & $\begin{array}{l}\text { Telefone, cartas, } \\
\text { bilhetes, visitas }\end{array}$ & $\begin{array}{l}\text { Se diz comunitária } \\
\text { mas pouco diferencia } \\
\text { da convencional }\end{array}$ & $\begin{array}{l}\text { SIM, ligada ao } \\
\text { PCdoB }\end{array}$ \\
\hline Progresso & 104,9 & $\begin{array}{l}\text { Lagoa do } \\
\text { Barro do } \\
\text { Piauí }\end{array}$ & 4.543 & 0,597 & $542 \mathrm{~km}$ & SIM & $\begin{array}{c}\text { Telefone, cartas, } \\
\text { bilhetes }\end{array}$ & $\begin{array}{l}\text { Se diz comunitária } \\
\text { mas pouco diferencia } \\
\text { da convencional }\end{array}$ & $\begin{array}{c}\text { NÂO, mas é } \\
\text { ligada à prefe. }\end{array}$ \\
\hline Redenção & 88,1 & $\begin{array}{l}\text { Redenção } \\
\text { do } \\
\text { Gurguéia }\end{array}$ & 8.263 & 0,583 & $691 \mathrm{~km}$ & SIM & $\begin{array}{l}\text { Cartas, bilhetes, } \\
\text { visitas }\end{array}$ & $\begin{array}{l}\text { Tenta ser comunitária. } \\
\text { Faz lutas ecológicas e } \\
\text { parcerias com } \\
\text { colégios } \\
\end{array}$ & SIM, ao PSDB \\
\hline Serra & 97,3 & $\begin{array}{c}\text { São } \\
\text { Francisco } \\
\text { de Assis } \\
\text { do Piauí } \\
\end{array}$ & 5.150 & 0,520 & $499 \mathrm{~km}$ & SIM & $\begin{array}{l}\text { Telefone, cartas, } \\
\text { bilhetes, visitas }\end{array}$ & $\begin{array}{l}\text { Tenta ser comunitária } \\
\text { com ligação de } \\
\text { agentes pastorais }\end{array}$ & $\begin{array}{l}\text { NÃO, mas } \\
\text { ligada ao } \\
\text { PSDB }\end{array}$ \\
\hline $\begin{array}{l}\text { Terceiro } \\
\text { Milênio }\end{array}$ & 105,9 & $\begin{array}{l}\text { Dom } \\
\text { Expedito } \\
\text { Lopes }\end{array}$ & 6.532 & 0,635 & $281 \mathrm{~km}$ & SIM & $\begin{array}{l}\text { Telefone, cartas, } \\
\text { bilhetes, visitas }\end{array}$ & $\begin{array}{l}\text { Se diz comunitária, } \\
\text { tenta dar espaço para } \\
\text { vários setores } \\
\text { populares }\end{array}$ & $\begin{array}{l}\text { SIM, com o } \\
\text { PSB }\end{array}$ \\
\hline Tribuna & 92,7 & $\begin{array}{c}\text { Pimenteira } \\
\mathrm{s}\end{array}$ & 11.722 & 0,574 & $252 \mathrm{~km}$ & NÂO & $\begin{array}{c}\text { Telefone, cartas, } \\
\text { bilhetes, visitas, } \\
\text { ajuda em } \\
\text { programa } \\
\text { voltado à } \\
\text { comunidade } \\
\end{array}$ & $\begin{array}{l}\text { Tenta ser comunitária } \\
\text { e em seu jeito de ser } \\
\text { vem conseguindo } \\
\text { apesar das } \\
\text { dificuldades }\end{array}$ & $\begin{array}{l}\text { NÃO, mas são } \\
\text { ligados ao PT }\end{array}$ \\
\hline $\begin{array}{c}\text { Tribuna } \\
\text { Cantoese }\end{array}$ & 107,9 & $\begin{array}{l}\text { Canto do } \\
\text { Buriti }\end{array}$ & $\begin{array}{l}20 . \\
673\end{array}$ & 0,616 & $405 \mathrm{~km}$ & NÃO & Fechada & Dizia que sim & $\begin{array}{l}\text { NÃO, mas } \\
\text { tudo é respon- }\end{array}$ \\
\hline
\end{tabular}


Revista de Comunicação e Cultura no Semiárido (ComSertões)

\begin{tabular}{|c|c|c|c|c|c|c|c|c|c|}
\hline & & & & & & & & & $\begin{array}{l}\text { dido por uma } \\
\text { só pessoa }\end{array}$ \\
\hline Umbuzeiro & 105,9 & Pio IX & 17.123 & 0,572 & $434 \mathrm{~km}$ & SIM & $\begin{array}{l}\text { Telefone, cartas, } \\
\text { bilhetes, visitas }\end{array}$ & $\begin{array}{l}\text { Diz que já foram, hoje } \\
\text { estão desmotivados }\end{array}$ & SIM, ao PSB \\
\hline $\begin{array}{l}\text { Vale do } \\
\text { Itain }\end{array}$ & 104,9 & Itainópolis & 11.084 & 0,585 & $356 \mathrm{kM}$ & $\mathrm{NÂO}$ & $\begin{array}{l}\text { Carta, visita, } \\
\text { bilhete }\end{array}$ & Não tem & $\begin{array}{c}\text { SIM, ligado ao } \\
\text { PT }\end{array}$ \\
\hline $\begin{array}{l}\text { Vale do } \\
\text { Sambito }\end{array}$ & 87,9 & $\begin{array}{l}\text { São Félix } \\
\text { do Piauí }\end{array}$ & 3.132 & 0,524 & $157 \mathrm{~km}$ & SIM & $\begin{array}{c}\text { Telefone, cartas, } \\
\text { bilhetes, visitas }\end{array}$ & $\begin{array}{c}\text { Se diz comunitária, } \\
\text { mas segue passos de } \\
\text { convencional }\end{array}$ & $\begin{array}{l}\text { SIM, com o } \\
\text { PMDB }\end{array}$ \\
\hline $\begin{array}{c}\text { Vale } \\
\text { Esperança }\end{array}$ & $\begin{array}{l}\text { Ainda } \\
\text { não } \\
\text { tem }\end{array}$ & $\begin{array}{c}\text { Queimada } \\
\text { Nova }\end{array}$ & 9.146 & 0,532 & 522 km & SIM & Não está no ar! & Não está no ar! & SIM, com o PT \\
\hline $\begin{array}{l}\text { Verdes } \\
\text { Canas }\end{array}$ & 101,3 & Boa Hora & 6.086 & 0,536 & $137 \mathrm{~km}$ & NÃO & $\begin{array}{c}\text { Telefone, cartas, } \\
\text { bilhetes, visitas }\end{array}$ & $\begin{array}{l}\text { Se diz comunitária, } \\
\text { mas age como uma } \\
\text { convencional }\end{array}$ & $\begin{array}{l}\text { SIM, ao DEM, } \\
\text { e ao prefeito } \\
\text { da cidade }\end{array}$ \\
\hline Veredas & 87,9 & Simões & 13.734 & 0,565 & $440 \mathrm{~km}$ & SIM & $\begin{array}{c}\text { Telefone, cartas, } \\
\text { bilhetes, visitas }\end{array}$ & $\begin{array}{l}\text { Se diz e quer ser } \\
\text { comunitária }\end{array}$ & $\begin{array}{l}\text { NÃO, apesar } \\
\text { de ligação } \\
\text { com PT }\end{array}$ \\
\hline $\begin{array}{l}\text { Villa dos } \\
\text { Humildes }\end{array}$ & 87,9 & Alto Longá & 13.612 & 0,580 & $76 \mathrm{~km}$ & NÃO & $\begin{array}{c}\text { Telefone, cartas, } \\
\text { bilhetes }\end{array}$ & $\begin{array}{l}\text { Se assume como } \\
\text { rádio convencional }\end{array}$ & $\begin{array}{l}\text { SIM, a político } \\
\text { da cidade que } \\
\text { busca o poder }\end{array}$ \\
\hline
\end{tabular}

FONTE: Dados do autor cruzados com Censo 2007 (IBGE, 2008), pesquisa de campo do autor e Mapa Rodoviário do Piauí (DER-PI, 1998).

\section{VI - Experiências emblemáticas nas rádios comunitárias do Sertão do Piauí}

Como exemplos emblemáticos de rádios comunitárias legalizadas no sertão do Piauí destacam-se emissoras radiofônicas que têm diferenciais positivos em relação à comunicação comunitária nessa região do País, principalmente por seus papéis enquanto meios de comunicação social dedicados à região sertaneja nordestina. Essas emissoras também refletem e instigam peculiaridades visando o desenvolvimento sertanejo local. São rádios que contribuem com melhorias e desenvolvimentos das áreas geográficas em que estão instaladas. Não são simples meios de comunicação tocadores de músicas ou de participação passiva (como solicitação de veiculação de músicas do momento ou de simples difusões de recados).

Entre elas há FMs que contrastam com as outras utilizadas como serventia de grupos políticos ou grupos segmentados de poder econômico e social, que atualmente, por conta da multiplicação de influência político-partidária-econômica, notadamente na região do Sertão do Nordeste. Estas também se aproveitam das brechas da Lei das Rádios Comunitárias, aumentando seus controles e o lobby visando a concessão e instalação de rádios tidas como comunitárias que, ao contrário dos exemplos emblemáticos, desvirtuam o movimento de emissoras 
comprometidas com o social deixando cidades, e até regiões, inteiras sem um meio de comunicação realmente representativo.

Chegou-se ao termo "emblemático" após analisar as diferenciações dessas emissoras não só como meios de comunicação comunitários ou locais nas 151 cidades do sertão do Piauí, mas também em relação aos diferenciais positivos perante rádios das regiões em que estão inseridas. Apontam-se nove emissoras classificadas como exemplos emblemáticos de comunicação comunitária radiofônica no sertão do Piauí, ocorrido após pesquisas de campo ${ }^{10}$ junto às 30 primeiras emissoras de rádio comunitária legalizadas nessa região do País até o dia 31 de janeiro de 2009. Após comparações e visitas ${ }^{11}$, são consideradas emblemáticas as emissoras sertanejas comunitárias: FM Família; FM Liberdade; FM Malhada do Jatobá; FM Matões; FM Terceiro Milênio; Redenção FM; Serra FM; Tribuna FM e Veredas FM.

A FM Família é considerada como emblemática por seus diferenciais em relação às outras rádios da cidade (inclusive as tidas como comunitárias), por sua história de luta (de mais de década para se tornar legalizada, inclusive com prisões, arbitrariedades e multas), por suas formas de participação da população e, principalmente, em relação aos movimentos sociais e às entidades, e por suas formas de participação virtual, através da Internet.

Outro exemplo é a FM Liberdade, por sua diferenciação como emissora sertaneja cem por cento evangélica, por sua forma de integrar o público evangélico do mais antigo município do sertão do Piauí, por respeitar os outros credos evangélicos da região, realizando programação sem anúncios comerciais e com informações com uma filtragem de emissão diferente de quase todas as outras emissoras de rádio do Piauí.

A FM Malhada do Jatobá é outro exemplo por sua história de luta (de mais de uma década), por suas maneiras de gestão compartilhada do comando da emissora pelos movimentos sociais da cidade, inclusive as minorias, e devido suas formas de tentativa de resgate cultural e manutenção dos preceitos sertanejos piauienses, via

\footnotetext{
${ }^{10}$ Feitas durante dois anos após visitas a todas as rádios comunitárias legalizadas do sertão do Piauí até 01 ํㅡês de 2008.

${ }^{11}$ Visitas ocorridas entre janeiro de 2007 e janeiro de 2009. E comparações ocorridas durante quase todo o ano de 2008.
} 
programação e ações de cidadania no dia a dia dos microfones e ações desse meio de comunicação.

A FM Matões, também é destacada positivamente por suas lutas históricas para se manter funcionando, interagindo e beneficiando a comunidade da cidade e região, em contraponto às duas históricas emissoras de rádio que funcionam em Pedro II. Também tem diferencial porque tem visões e ações diferentes de ser comunitária (principalmente no sentido teórico), mas envereda por vivências coletivas de meios de comunicação, além de instigar lutas e participações comunitárias através do que é transmitido pela rádio.

A FM Terceiro Milênio, por sua forma integracionista entre moradores da zona urbana e zona rural da cidade, como única voz do município e ainda como meio de comunicação a trazer para a localidade assuntos nacionais e estaduais, tornando o entender "local" e o compreender a vida do município: fatos conhecidos e com possibilidades de debates, e assim, de proporcionar melhorias sociais antes inexistentes em Dom Expedito Lopes.

A Redenção FM, também como única voz em raio de quase cem quilômetros, com campanhas educativas, formas de instigar e mobilizar a participação em uma das áreas mais isoladas do Piauí e também de debater questões ecológicas, econômicas e políticas da região.

Já a Serra FM é tida como emblemática por sua forma de beneficiamento do homem do campo (hoje extrema maioria da população do município), com seu exemplo de agentes comunitários de rádio comunitária (que atuam na zona rural e que utilizam a FM para socializar conhecimentos) e participação em campanhas sociais e integração da população da cidade, que é uma das cinco mais isoladas do Piauí.

A Tribuna FM tem forte destaque por sua forma de fazer rádio comunitária através de ideias sindicais e movimentos sociais sertanejos, por seus exemplos de tentativa de valorização da comunidade e vivências coletivas no sertão do Piaú, principalmente porque o município é um dos cinco maiores do Piauí em termos de extensão territorial.

E a Veredas FM por sua história, fruto de um grupo de jovens pensadores que lutam durante há quase duas décadas pelo desenvolvimento da região em que estão 


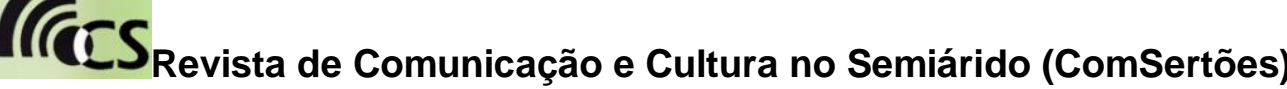

inseridos e que viram em um meio de comunicação uma forma de pluralizar mais esses ideais. A rádio também tem grande destaque por sua atuação como forma de construção coletiva e por suas idas e vindas, entremeio a se fazer comunicação comunitária em uma das áreas mais conturbadas (política e socialmente) do Piauí.

Essas nove emissoras, entremeio às rádios comunitárias sertanejas piauienses, também se diferenciam em termos gerais e com características parecidas (em relação às outras rádios comunitárias legalizadas sertanejas e até a quase totalidade de rádios dessa região do País) por conta de suas aproximações de função comunitária (ou sensação de função comunitária), função e importância local (integradora e preocupada com o dia a dia da localidade e melhores dias para seus moradores), função regional (de serem um meio de interligação e desenvolvimento de várias cidades, também integrando regiões antes desagregadas), função de instigar a participação ou desenvolvimento social e de diferenciação positiva em relação aos processos comunicacionais nessa região do País. 


\section{Referências}

AGUIAR, Vera Teixeira de. O verbal e o não verbal. São Paulo: Unesp, 2004.

BAUMAN, Zygmunt. Comunidade - a busca por segurança no mundo atual. Rio de Janeiro: Jorge Zahar, 2003.

BAZI, Rogério Eduardo Rodrigues. TV Regional - Trajetórias e Perspectivas. Campinas: Alínea, 2001.

BERLO, David K. O Processo da Comunicação. Rio de Janeiro: Editora Fundo de Cultura, 1972.

BERTI, Orlando Maurício de Carvalho. A histórica exclusão do Sertão nordestino. Como as comunidades sertanejas do Piauí têm o menor número de rádios comunitárias do Brasil. Niterói: CD-Rom do VI Encontro da Rede Alcar - de História da Mídia, 2008.

BUBER, Martin. Sobre Comunidade. São Paulo: Perspectiva, 1987.

COGO, Denise Maria; PERUZZO, Cicília Maria Krohling (orgs). Vozes Cidadãs Aspectos Teóricos e Análises de Experiências de Comunicação Popular e Sindical na América Latina. São Paulo: Angellara Editora, 2004.

FADUL, Anamaria. Mídia Regional no Brasil: elementos para uma análise. In: FADUL, Anamaria; GOBBI, Maria Cristina (orgs.). Mídia e região na era digital diversidade cultural e convergência midiática. São Paulo: Arte e Ciência, 2006.

FERRARETO, Luiz Artur. Rádio - o Veículo, a História e a Técnica. Porto Alegre: Sagra Luzzato, 2001.

IBGE - INSTITUTO BRASILEIRO DE GEOGRAFIA E ESTATÍSTICA. População, segundo crenças religiosas no. Disponível em: <http://www.ibge.gov.br/home/>. Acesso em: 04 jan.2009.

População e área do Brasil. Disponível em: <http://www.ibge.gov.br/home/>. Acesso em: 04 jan.2009.

População e área dos municípios do sertão do Piauí. Disponível em: <http://www.ibge.gov.br/cidadesat/topwindow.htm?1>. Acesso em: 28 dez.2008.

IBGE - INSTITUTO BRASILEIRO DE GEOGRAFIA E ESTATÍSTICA - MAPAS ESCOLARES. Mapa do Semi-árido brasileiro. Disponível em: <http://www.ibge.gov.br/paisesat/main.php>. Acesso em: 04 jan.2009.

IBGE - INSTITUTO BRASILEIRO DE GEOGRAFIA E ESTATÍSTICA - PAÍSES. Países do Mundo. Disponível em: 
<ftp://geoftp.ibge.gov.br/Organizacao/Semi_Arido/Semi_Arido_Brasileiro.pdf>. Acesso em: 04 jan.2009.

LÓPEZ VIGIL, José Ignácio. Manual Urgente para radialistas apaixonados. São Paulo: Paulinas, 2003.

MAPA RODOVIÁRIO DO PIAUÍ. Teresina: DER-PI - Departamento de Estradas e Rodagens do Piauí, 2006.

MATTELART, Armand; MATTELART, Michele. História das teorias da comunicação. São Paulo: Loyola, 2003.

MENEZES, José Eugênio de Oliveira. Rádio e cidade - Vínculos Sonoros. São Paulo: Annablume, 2007.

MINISTÉRIO DAS COMUNICAÇÕES. Como instalar uma rádio comunitária manual de orientação. Brasília: Ministério das Comunicações, 2007.

Lista das rádios comunitárias legalizadas do Brasil. Disponível em: <http://www.mc.gov.br>. Acesso em: 29 dez.2008.

- O que é uma rádio comunitária. Disponível em: <http://www.mc.gov.br/radio-comunitaria/o-que-e>. Acesso em: 05 jan.2009.

Brasil. Disponível em: <http://www.mc.gov.br/radio-comunitaria/processosautorizados>. Acesso em: 01 jan.2009.

PAIVA, Raquel. O retorno da comunidade - os novos caminhos do social. Rio de Janeiro: Mauad X, 2007.

PALÁCIOS, Marcos. O medo do vazio: Comunicação, socialidade e novas tribos. In: RUBIM, Antônio Albino (org.). Idade Mídia. Salvador: Edufba, 1995.

PERUZZO, Cicília Maria Krohling. Comunicação comunitária e educação para a cidadania. In: BARBOSA, Marialva (org.). Vanguarda do Pensamento Comunicacional Brasileiro: as contribuições da Intercom (1977-2007). São Paulo: Intercom, 2007(a).

Comunicação nos Movimentos Populares a participação na construção da cidadania. Petrópolis: Vozes, 1998(b).

Mídia Comunitária. Comunicação e Sociedade: Revista do Programa de Pós-Graduação em Comunicação Social. São Bernardo do Campo: Umesp, n.30, 1998(a). pp.141-156. 


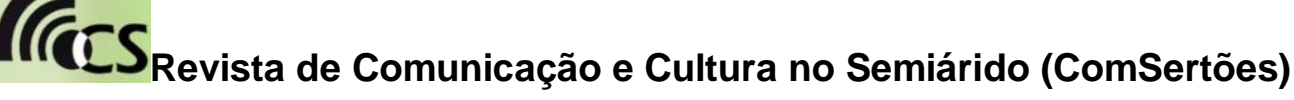

Participação nas rádios comunitárias no Brasil. BOCC - Biblioteca Online de Ciências da Comunicação. 1998 (c). Disponível em: <http://www.bocc.ubi.pt> Acesso em: 20 jan.2008.

Mauad X, 2007(b).

Televisão Comunitária. Rio de Janeiro:

PNUD - PROGRAMA DAS NAÇÕES UNIDAS PARA O DESENVOLVIMENTO BRASIL. Atlas do Desenvolvimento Humano no Brasil. Disponível em: <http://www.pnud.org.br/atlas/>. Acesso em: 30 dez.2008.

SECRETARIA DE FAZENDA DO PIAUÍ. Sistema de Legislação do Estado do Piauí - Decreto № 11.292, de 19 de janeiro de 2004. Disponível em: $<$ http://www.sefaz.pi.gov.br/scan/pages/jsp/scan/consultaDeAtoNormativo.jsp?idAto Normativo=4926 $>$. Acesso em: 01 jan.2009.

SOUSA, Jorge Pedro. Comunicação regional e local na Europa Ocidental - os casos português e galego. In: Anuário Unesco/Umesp de Comunicação Regional. São Bernardo do Campo: UMESP, ano 7, n.07, janeiro de 2003.

TÖNNIES, Ferdinand. Determinação geral dos conceitos principais. In: MIRANDA, Orlando de (org). Para ler Ferdinand Tönnies. São Paulo: Edusp, 1995. 